\title{
Australian Journal of Nursing Research
}

\section{Developing a Questionnaire to Assess the Perception, Knowledge, And Attitude of Nursing Students in Providing Oral Health Care to Older People, And Associated Influential Factors}

Bhagat $\mathrm{V}^{1^{*}}$, Hoang $\mathrm{H}^{2}$, Crocombe $\mathrm{LA}^{3}$ and Goldberg $\mathrm{LR}^{4}$

${ }^{1} \mathrm{PhD}$ candidate, Centre for Rural Health, E Block, Newnham Campus, University of Tasmania (UTAS), Australia

${ }^{2}$ Senior Research Fellow, CRH, E block, Newnham Campus, UTAS, Australia

${ }^{3}$ Professor of Rural Oral Health, Department of Dentistry \& Oral Health, Rural Health School, College of Science Health and Engineering, La Trobe University

${ }^{4}$ Associate Professor, Wicking Dementia Research \& Education Centre Room, Australia

"Corresponding author: Vandana Bhagat, Centre for Rural Health, E Block, Newnham Campus, University of Tasmania (UTAS), Australia, Email: vandana.bhagat@utas.edu.au

Citation: Bhagat V, Hoang H, Crocombe LA, Goldberg LR (2021) Developing A Questionnaire to Assess The Perception, Knowledge, And Attitude of Nursing Students in Providing Oral Health Care to Older People, And Associated Influential Factors. Aus J Nursing Res. AJNR-100030. DOI:10.53634/2652-9386.100030

Received date: 08 July, 2021; Accepted date: 14 July, 2021; Published date: 20 July, 2021

\footnotetext{
Abstract

Objective: Developing a questionnaire to assess the perception, knowledge, and attitude of nursing students in providing oral health care to older people, and associated influential factors.

Background: The COVID-19 pandemic and associated restrictions to dental services have had a notable impact on the increase in older people's oral and associated systemic health problems, impacting their quality of life. Though COVID-19 is of viral origin, many older people have developed severe complications from this virus due to bacterial superinfections associated with poor oral health. This pandemic has emphasised the need to include preventive oral health care in holistic nursing care for older people. Nurses play a leading role in holistic and interprofessional care that supports healthy ageing.

Study design and methods: The questionnaire was developed following a standardised protocol consisting of a literature review, group discussions, and expert opinions. The 49-item questionnaire was then pilot tested through a cross-sectional online survey conducted with 26 participants in Australia who were recent nursing graduates or about to graduate with a Bachelor of Nursing degree.

Results: The questionnaire demonstrated satisfactory content, face, and construct validity. The internal consistency (reliability) as measured by Cronbach's alpha coefficient, of the perception, knowledge, and attitude sections of the questionnaire was $0.82,0.76$, and 0.60 , respectively.

Discussion and conclusions: The questionnaire is suggested as a helpful beginning to systematically evaluate what nursing students have learned about oral health care for older adults in their Bachelor of Nursing programs, their perception and attitude about providing such care, and identifying influential factors such as age, gender, experience, nationality, and geographic location, and working in interprofessional teams. Completion of the questionnaire by a larger number of participants will be valuable to confirm these psychometric results.

Impact: Using this questionnaire to identify gaps in the oral health education of nursing students will assist educators and increase students' awareness of the association between oral and systemic health and prepare them for holistic and effective nursing practice. Nursing graduates skilled in providing oral health care through interprofessional practice can improve older people's oral and systemic health.
} 


\section{List of abbreviations}

CINAHL : Cumulative Index to Nursing and Allied Health Literature

OECD : Organisation of Economic Co-operation and Development

Keywords: Aged; Dental care; Mouth care; Nurse; Oral disease; Survey

\section{What is already known about the topic:}

- Older people who do not have the capacity for effective selfcare are at a greater risk of oral diseases and poorer systemic health than people who can provide their own care.

- Oral health care of older people often receives a low priority in nursing activities.

- There is a lack of validated survey instruments to evaluate nursing students' knowledge of, and attitude towards providing oral health care to older people and associated factors.

\section{What this paper adds:}

- A questionnaire to determine undergraduate nursing students' current academic and clinical education about oral health care and how it may be strengthened, has been developed and piloted.

- Oral health care of older people needs to be an integral part of nursing education.

- Recognising the importance of oral health will strengthen and promote holistic nursing.

\section{Introduction}

The oral health of older people (65 years or above) is of increasing concern for health and social policymakers [1-4]. Poor oral health, with associated gum disease, dental caries, tooth loss, ill-fitting dentures, and pain adversely affects older people's ability to eat, speak, and engage socially, increasing their risk of malnutrition, frailty, and social isolation $[2,4]$. The aspiration of saliva, bacterial loci and food residue from an unhealthy mouth into the lungs can result in pneumonia and declining health [5]. The transfer of blood-borne bacteria from an unhealthy mouth can result in systemic infections and exacerbate chronic health conditions such as diabetes and cardiovascular disease, resulting in unplanned hospitalisations [5]. Many older people are dependent on others to maintain their oral health due to impaired cognitive ability, reduced motor and sensory skills, frailty related to co-morbidities, complications from intake of multiple medications, and sometimes anxiety due to lack of knowledge about maintaining oral health [6]. In 2019, the Australian Royal Commission into Aged Care Quality and Safety concluded that insufficient attention is being paid to the oral health care, nutrition, and hydration needs of older people, particularly those in residential care [7]. The COVID-19 pandemic has exacerbated this issue $[8,9]$.
Nurses play an important role in maintaining older people's oral health care [10]. Oral health care in nursing entails understanding the factors affecting people's oral health and oral health-related quality of life, ensuring daily oral care practice, and being able to complete an oral health screening in collaboration with dental, medical, and allied health professionals [11]. Nurses have the professional responsibility to ensure daily oral care for older people in acute, subacute, and rehabilitation wards of hospitals [11]. They guide and supervise personal assistants in residential aged care and community care and can ensure that evidence-based daily oral health care becomes a routine component of holistic and multifaceted nursing care $[12,13]$. However, a recent systematic review of 11 eligible studies from multiple countries highlighted the variability in nursing education about oral health and its relationship to general health. In addition, this systematic review documented the lack of validated survey instruments to evaluate nursing students' knowledge of, and attitude towards providing oral health care to older people and associated influential factors such as age, gender, experience, nationality, and geographic location [11]. An evaluation of the curriculum of Bachelor of Nursing programs in Australia, through details provided on university websites, identified no information regarding the oral health care of older people and no unit with a focus on the anatomy and physiology of the oral cavity and identification and care of common oral diseases. Components of oral health care may be embedded in existing units but the apparent lack of emphasis on the importance of oral health and its relationship to systemic health, particularly for older adults, was striking.

The provision of limited oral health care education to undergraduate nursing students can be the root cause of the gap in ensuring older people receive effective oral health care $[14,15]$. Increasing the focus on oral health care in academic and clinical undergraduate nursing programs will encourage nurses to practice effective and integrated oral health care [16].

Aims: This study aimed to develop and pilot test a questionnaire:

1. To assess the perception, knowledge, and attitude of final year undergraduate nursing students in providing oral health care to older people;

2. Determine associated influential factors;

3. Identify ways in which the evaluation of academic and clinical education about oral health care may be strengthened.

\section{Materials And Methods}

Theoretical framework for the study: The knowledgeattitude-practice-outcome (KAP-O) framework proposed by Wan underpinned the development of the questionnaire [17]. This framework suggests that educational interventions improve knowledge and attitude. Improved knowledge and attitude, in turn, directly enhances practice; a step toward improved health outcomes [17]. 
Development of the questionnaire: The development of the questionnaire involved two phases - item generation and organisation, and pilot testing. In brief, the item generation and organisation phase followed a standardised protocol that encompassed a literature review, group discussions, and expert review and evaluation (Phase 1). Pilot testing (Phase 2) was done through a cross-sectional online survey conducted with 26 participants who were recent graduates or were about to graduate with a Bachelor of Nursing degree in Australia.

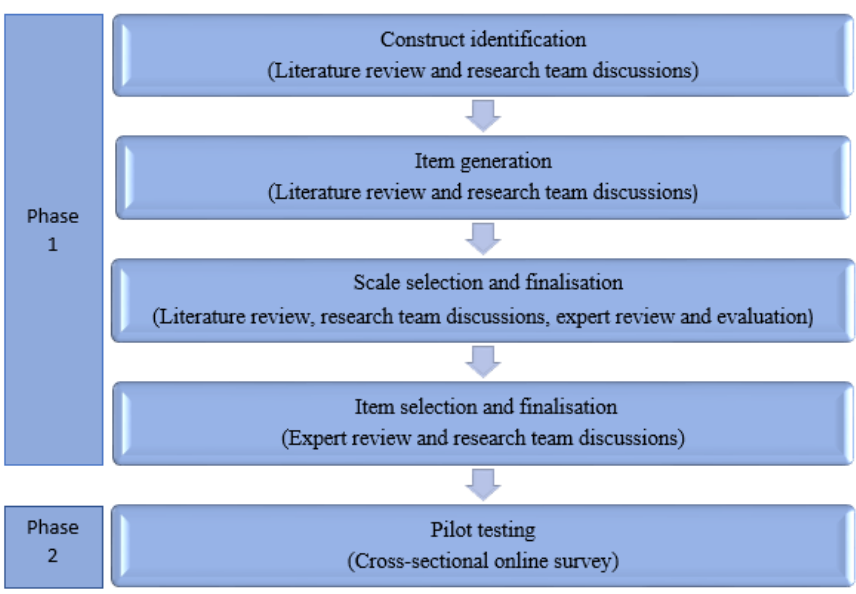

Figure: The two phases in the development of the questionnaire.

\section{Phase 1: Item generation and organisation}

- Step 1: Identification of underlying constructs: The first step in generating the items for the questionnaire included the identification of six operational constructs. Well-defined constructs facilitate the process of item generation and content validation [18].The six recognised constructs and their definitions for nursing practice follow:

- Background/Associated factors: Variables such as age, gender, experience, nationality, and geographic location that influence nursing students' knowledge acquisition and attitude towards providing oral health care for older people.

- Oral health care in nursing for older people: Oral health care for older people entails ensuring evidence-based daily oral care, being able to complete an oral health screening, and collaborating with dental, medical, and allied health professionals [11].

- Perception of self-efficacy: Opinions of nursing students about their ability to provide effective oral health care for older people [19].

- Knowledge: Nursing students' awareness and understanding of basic components in providing oral health care for older people [20].

- Attitude: An attribute expressing nursing students' beliefs, feelings, and interest towards providing oral health care for older people [21].
- Personal oral health behaviour: Self-care practice of nursing students to maintain their oral health.

Step 2: Item generation: Potential items to measure the six identified constructs were generated deductively through a literature review and assessment of existing published instruments that evaluated nursing students' education, attitude, and knowledge towards oral health care for older people [11]. A primary search was conducted through three databases, PubMed, CINAHL, and Scopus. From a pool of 567 articles, 11 addressed oral health education in nursing and four evaluated nursing students' attitude and knowledge about oral health care through questionnaires and/or surveys [14, 2224]. None included a focus on the oral health care needs of older people. A secondary search was conducted through the internet search engines 'Google' and 'Google Scholar' but did not identify any further published valid and reliable tools, confirming the need for the development of the current questionnaire.

The wording of relevant items in existing tools that evaluated nursing staff knowledge and attitude was adapted to focus on the oral health care of older people [14, 22]. Additional items were developed based on the literature and guidelines on older people's oral health care in nursing. In total, 76 items were generated for the initial version of the questionnaire.

Step 3: Scale selection: A Likert-type 5-point response scale was used for all items addressing perception, knowledge, and attitude as follows: $5=$ strongly agree, $4=$ agree, $3=$ neither agree or disagree, $2=$ disagree, and $1=$ strongly disagree. Scores were reversed for negative items. Cross-sectional and test-retest reliability for 5-point scales has been established as equal to scales with 7, 9, and 14-point ranges [25]. Initially, a "Yes, No, Don't Know" scale was selected to measure knowledge items but was changed to the 5-point scale following feedback from a statistician. Answering yes/ no questions requires respondents to answer a comparable rating question with construct-specific response options. Consequently, it was considered best to avoid yes/no formats and use 5-point rating scales that present an evaluative dimension [25].

Other sections of the questionnaire included items that required yes/no answers, brief responses, single-choice, and multiple-choice answers. Optional open-ended questions were provided at the end of the questionnaire to add richness to survey results. Such open-ended options are useful for clarifying constructs that are difficult to achieve with close-ended questions, for example, suggestions as to how oral health care could be incorporated effectively in nursing education.

Step 4: Item confirmation: This step focussed on establishing the content validity of the selected items on the draft questionnaire. Formal statistical testing is not required to ensure content validity, but the item generation process needs to include a review of published data and literature by an expert panel to assess item relevance [26].

An expert review panel comprised of six experts from statistical, nursing, public health, food science, and dental and 
medical backgrounds, was established to provide feedback on the questionnaire items. The feedback on the preliminary version of the questionnaire was then examined inductively through discussions with co-authors (LC, LG, HH), all experienced clinical researchers in oral health care for older people. Items were removed, refined, and replaced by consensus, resulting in 49 items.

The revised questionnaire was then sent to an additional four nursing experts, three teaching staff, and one field researcher, all with experience in older people's oral health care. Minor wording changes were made for clarity, more possible options were added to one item, and items were confirmed.The final 49-item questionnaire is provided at the end of this paper (Attachment 1). It is organised as follows to address the six operational constructs:

- Construct 1-Background/Associated factors: Single choice and brief responses documenting demographic information regarding nationality, geographic location, age group, and gender (5 items)

- Construct 2-Oral health care in nursing for older people: Yes/No questions documenting nursing students' current exposure to oral health care for older people; any previous exposure; and whether oral health care for older people was included in their nursing education (3 items). A "yes" response to an item directs participants to seven sub-questions (single choice, multiple-choice, and brief responses) for further information

- Construct 3-Perception of self-efficacy: Likert-type 5-point scale responses to five statements about ability to provide basic oral health care to older people: understanding of factors affecting the oral health of older people; awareness of effective daily oral health activities; education about making a timely referral for comprehensive oral health assessments by dental professionals; understanding of the relationship between oral and systemic health; and the ability to train and supervise personal assistants providing oral health care to older people.

- Construct 4-Knowledge: Likert-type 5-point scale responses to 15 statements evaluating nursing students' awareness and understanding of basic components in providing oral health care to older people. Items in the knowledge scale will enable a comparison of the students' perceptions of what they know and can do compared to their actual knowledge.

- Construct 5-Attitude: Likert-type 5-point scale responses to five statements about attitude towards providing oral health care to older people: focusing on the importance of the role of nurses in providing oral health care to older people, and students' interest in learning about providing effective oral health care.

- Construct 6-Personal oral health behaviour: Single choice responses to four statements that evaluate students' self-care behaviour regarding oral health: brushing habits, frequency of using interdental brushes, the usual reason for a dental visit, and level of apprehension about visiting a dentist. Items under this Construct enable the association of the students' own oral health care behaviour with their provision of oral health care to older people, as measured under Construct 3.

- Concluding questions: Yes/No, responses and open-ended questions to encourage feedback from students regarding strategies to strengthen oral health education and clinical preparation in nursing curricula (5 items).

\section{Phase 2: Pilot testing of the questionnaire}

Sample size of participants: Guidelines for respondent-to-item ratio vary, ranging from 5:1, 10:1, or 30:1 [18,27,28]. Given that reliability coefficients are not substantially impacted by sample size, reliability can be tested by collecting data from 20 to 30 participants [29]; thus, recruiting 26 participants to complete the 49 items on the questionnaire was considered adequate.

Procedure: Convenience and snowball sampling techniques were used to recruit final year nursing students and recent graduates from accredited Bachelor of Nursing programs in Australia to test the validity and reliability of the 49-item questionnaire.

Initially, the 26 participants were recruited to take part in the pilot testing of the questionnaire via an online Lime survey fielded between September and early November 2020. Six participants provided incomplete responses, and their questionnaires were excluded from the data analysis. Following analysis of the data from the remaining 20 participants, these participants were sent a further survey invitation in late November and early December 2020 to re-assess the reliability of amended items in the attitude section of the questionnaire. Out of the 20 participants re-surveyed, only 15 completed the assessment of the amended items on the attitude scale.

\section{Data analysis}

Data from the returned questionnaires were uploaded into SPSS (Statistical Package for the Social Sciences) version 22 for analysis of reliability (internal consistency) and content, face, and construct validity. The reliability of the questionnaire items was computed using Cronbach's alpha coefficient. This coefficient is commonly used and ranges from 0 to $1 ; 0.50$ or below represents low reliability, 0.50 to 0.70 represents moderate reliability, and 0.7 to 0.9 represents high reliability. A value greater than 0.9 is of concern as it may indicate an inefficient level of redundancy in items [30]. While Cronbach's alpha is sensitive to the number of items being analysed and the number of responding participants, many researchers now recommend the use of the omega, rather than alpha coefficient to accommodate small samples and skewed distributions [31, 32]. To calculate omega, a zip file was downloaded from a website (omega.zip (afhayes.com)) developed by Prof Andrew F. Hayes and linked to the SPSS file [31]. Construct validity was ensured by assessing item-total correlations in each section.

\section{Ethical Considerations}

The development and validation of the questionnaire was part of a $\mathrm{PhD}$ project "Building future workforce capability: Nursing 
students' attitude and knowledge of older Australians' oral health care and strategies to improve students' competency". Ethics approval was received from the Tasmania Social Sciences Human Research Ethics Committee (ref no.H0020263). In line with ethical conditions, informed consent was obtained from all participants, and data privacy and confidentiality were maintained throughout the study.

\section{Results}

A total of 26 students including final year nursing students $(n=4)$ and recent graduates $(n=22)$ from 11 accredited Bachelor of Nursing programs in Australia completed the final version of the 49 -item survey. These 11 programs represented urban $(\mathrm{n}=9)$ and rural $(n=2)$ locations. Fifty percent $(n=13)$ of the participants were between 30 and 40 years of age; the remaining 13 were between 18 and 29 years of age. Females constituted above eighty percent $(n=22)$ of all participants.

Reliability: Items in the perception of self-efficacy and knowledge sections were highly reliable with Cronbach alpha coefficients of 0.82 and 0.76 , respectively (Tables 1 and 2 ).

\begin{tabular}{|c|c|c|c|c|c|}
\hline $\begin{array}{c}\text { Cronbach's Alpha } \\
0.87\end{array}$ & $\begin{array}{c}\text { Cronbach's Alpha Based on } \\
\text { Standardised Items } \\
0.9\end{array}$ & \multicolumn{4}{|c|}{$\begin{array}{l}\mathrm{N} \text { of Items } \\
\quad 5\end{array}$} \\
\hline \multicolumn{6}{|c|}{ Item-Total Statistics } \\
\hline- & Scale Mean if Item Deleted & $\begin{array}{c}\text { Scale } \\
\text { Variance if } \\
\text { Item Deleted }\end{array}$ & $\begin{array}{l}\text { Corrected } \\
\text { Item-Total } \\
\text { Correlation }\end{array}$ & $\begin{array}{c}\text { Squared } \\
\text { Multiple } \\
\text { Correlation }\end{array}$ & $\begin{array}{l}\text { Cronbach's } \\
\text { Alpha if Item } \\
\text { Deleted }\end{array}$ \\
\hline $\begin{array}{l}\text { I understand the factors affecting } \\
\text { the oral health of older people }\end{array}$ & 15.5 & 7.74 & 0.62 & 0.58 & 0.86 \\
\hline $\begin{array}{c}\text { I am aware of effective daily oral } \\
\text { health care activities }\end{array}$ & 15.45 & 8.15 & 0.79 & 0.72 & 0.84 \\
\hline $\begin{array}{l}\text { I am trained in making appropri- } \\
\text { ate timely referral to a dentist for } \\
\text { oral health assessment and care } \\
\text { of older people when required }\end{array}$ & 16.25 & 5.67 & 0.728 & 0.66 & 0.86 \\
\hline $\begin{array}{l}\text { I understand the relationship } \\
\text { between oral and systemic health }\end{array}$ & 15.55 & 8.37 & 0.83 & 0.79 & 0.84 \\
\hline $\begin{array}{l}\text { I am confident in training and } \\
\text { supervising care assistants in } \\
\text { providing oral health care to } \\
\text { older people }\end{array}$ & 16.05 & 6.26 & 0.81 & 0.71 & 0.81 \\
\hline
\end{tabular}

Table 1: Reliability statistics for the perception of self-efficacy scale Cronbach alpha test for items in the perception of self-efficacy section.

- Omega test for items in the perception of self-efficacy section: This estimate of omega was based on the factor loadings of a forced single-factor maximum likelihood factor analysis using SPSS' built in FACTOR procedure.

\section{Reliability Omega.88}

\begin{tabular}{lcccc}
\multicolumn{5}{c}{ Item means, standard deviations (SD), and estimated loadings: } \\
Mean & SD & Loading & Error Variance \\
$\mathrm{I} 1001$ & 4.20 & .77 & .57 & .26 \\
$\mathrm{I} 1002$ & 4.25 & .55 & .49 & .07 \\
$\mathrm{I} 1003$ & 3.45 & 1.14 & .83 & .62 \\
$\mathrm{I} 1004$ & 4.15 & .48 & .45 & .03 \\
$\mathrm{I} 1005$ & 3.65 & .93 & .74 & .33
\end{tabular}




\begin{tabular}{|c|c|c|c|c|c|}
\hline Cronbach's Alpha & $\begin{array}{l}\text { Cronbach's Alpha Based } \\
\text { on Standardised Items }\end{array}$ & \multicolumn{4}{|c|}{$\mathrm{N}$ of Items 15} \\
\hline \multicolumn{6}{|c|}{ Item-Total Statistics } \\
\hline- & $\begin{array}{l}\text { Scale Mean if Item } \\
\text { Deleted }\end{array}$ & $\begin{array}{l}\text { Scale Vari- } \\
\text { ance if Item } \\
\text { Deleted }\end{array}$ & $\begin{array}{l}\text { Corrected } \\
\text { Item-Total Cor- } \\
\text { relation }\end{array}$ & $\begin{array}{l}\text { Squared Mul- } \\
\text { tiple Correla- } \\
\text { tion }\end{array}$ & $\begin{array}{l}\text { Cronbach's } \\
\text { Alpha if Item } \\
\text { Deleted }\end{array}$ \\
\hline $\begin{array}{l}\text { Smoking does not affect the oral health } \\
\text { of older people with no natural teeth }\end{array}$ & 51.45 & 38.37 & 0.31 & 0.85 & 0.76 \\
\hline $\begin{array}{l}\text { Dry mouth problems are uncommon } \\
\text { among older people }\end{array}$ & 52.25 & 32.72 & 0.56 & 0.89 & 0.74 \\
\hline $\begin{array}{l}\text { The presence of string saliva in the } \\
\text { mouth of older people is normal }\end{array}$ & 52.4 & 37.41 & 0.31 & 0.99 & 0.76 \\
\hline $\begin{array}{l}\text { Fluoride toothpaste has no greater } \\
\text { benefit than non-fluoride toothpaste for } \\
\text { older people with natural teeth }\end{array}$ & 52.7 & 37.59 & 0.42 & 0.68 & 0.75 \\
\hline $\begin{array}{l}\text { A hard-bristled brush is better than soft } \\
\text { bristle brush for cleaning and removing } \\
\text { plaque from older people's teeth }\end{array}$ & 51.9 & 36.41 & 0.57 & 0.84 & 0.74 \\
\hline $\begin{array}{c}\text { Older people must brush their teeth } \\
\text { immediately after having carbonated } \\
\text { drinks }\end{array}$ & 52.75 & 36.51 & 0.38 & 0.77 & 0.76 \\
\hline $\begin{array}{l}\text { Swabs containing lemon and glycerin } \\
\text { should be used to clean the mouths of } \\
\text { people who have no teeth }\end{array}$ & 53.15 & 36.34 & 0.47 & 0.8 & 0.75 \\
\hline $\begin{array}{c}\text { Denture cleaning solutions clean the } \\
\text { dentures without you needing to brush } \\
\text { the denture }\end{array}$ & 52.65 & 36.98 & 0.3 & 0.88 & 0.76 \\
\hline $\begin{array}{c}\text { Denture should be taken out of the } \\
\text { mouth at night }\end{array}$ & 51.4 & 40.88 & 0.19 & 0.89 & 0.77 \\
\hline $\begin{array}{l}\text { Cracked corners around the mouth can } \\
\text { be treated with moisturiser }\end{array}$ & 53.5 & 40.16 & 0.12 & 0.76 & 0.77 \\
\hline $\begin{array}{l}\text { Bleeding gums while brushing do not } \\
\text { require a dental referral }\end{array}$ & 52.2 & 34.06 & 0.58 & 0.87 & 0.73 \\
\hline $\begin{array}{c}\text { Older people without natural teeth only } \\
\text { need a dental check-up when they have } \\
\text { a problem }\end{array}$ & 52.05 & 37.84 & 0.25 & 0.8 & 0.77 \\
\hline $\begin{array}{l}\text { Cardiovascular problems are associated } \\
\text { with dental infections }\end{array}$ & 52.15 & 36.24 & 0.32 & 0.76 & 0.76 \\
\hline $\begin{array}{l}\text { People with diabetes have a high risk } \\
\text { of gum diseases and vice-versa }\end{array}$ & 51.7 & 36.43 & 0.63 & 0.93 & 0.74 \\
\hline $\begin{array}{l}\text { Effective oral health care helps to } \\
\text { prevent aspiration pneumonia }\end{array}$ & 51.75 & 38.51 & 0.37 & 0.72 & 0.76 \\
\hline
\end{tabular}

Table 2: Reliability statistics for items in the knowledge scale. Cronbach alpha test for items in the knowledge section. 
- Omega test for items in the knowledge section: This estimate of omega was based on the factor loadings of a forced single-factor maximum likelihood factor analysis using SPSS' built in FACTOR procedure.

\section{Reliability Omega.77}

\begin{tabular}{|c|c|c|c|c|}
\hline \multicolumn{2}{|c|}{ Mean } & \multicolumn{3}{|c|}{ SD Loading Error Variance } \\
\hline J1001 & 4.55 & .76 & .30 & .48 \\
\hline $\mathrm{J} 1002$ & 3.75 & 1.21 & .65 & 1.04 \\
\hline J1003 & 3.60 & .94 & .15 & .86 \\
\hline J1004 & 3.30 & .73 & 36 & .41 \\
\hline J1005 & 4.10 & .79 & .42 & .34 \\
\hline J1006 & 3.25 & 97 & .33 & .82 \\
\hline J1007 & 2.85 & .93 & .33 & .76 \\
\hline J1008 & 3.35 & 1.04 & .39 & .92 \\
\hline J1009 & 4.60 & .50 & .14 & .23 \\
\hline J1010 & 2.50 & .76 & .13 & .56 \\
\hline J1011 & 3.80 & 1.00 & .78 & .40 \\
\hline J1012 & 3.95 & .99 & .29 & .91 \\
\hline J1013 & 3.85 & 1.14 & .42 & 1.11 \\
\hline J1014 & 4.30 & .66 & .54 & .14 \\
\hline J1015 & 4.25 & .64 & .28 & .33 \\
\hline
\end{tabular}

McDonald's omega also showed similar results with 0.87 and 0.76 reliability coefficients, respectively (Tables 1 and 2). The reliability of items in the attitude section was poor, with unacceptable Cronbach alpha and omega coefficient values of below 0.5 . This may be due to possible ambiguity in some items. After a thorough discussion with all authors, these items were revised, and responses to all items in the revised attitude section were obtained from the additional 15 participants. Reliability results for both Cronbach alpha and omega on the revised attitude scale remained below 0.5 . Two items with very low correlation coefficients were removed. Re-analysed Cronbach alpha and omega coefficients for the remaining five items on the revised attitude section had moderate reliability at 0.6 and 0.68 , respectively (Table 3 ).

\begin{tabular}{|c|c|c|c|c|c|}
\hline \multicolumn{6}{|c|}{ Cronbach alpha test in the revised attitude scale } \\
\hline $\begin{array}{c}\text { Cronbach's Alpha } \\
0.61\end{array}$ & $\begin{array}{c}\text { Cronbach's Alpha Based on } \\
\text { Standardised Items } \\
0.61\end{array}$ & \multicolumn{4}{|c|}{$\mathrm{N}$ of Items 5} \\
\hline \multicolumn{6}{|c|}{ Item-Total Statistics } \\
\hline- & Scale Mean if Item Deleted & $\begin{array}{l}\text { Scale Vari- } \\
\text { ance if Item } \\
\text { Deleted }\end{array}$ & $\begin{array}{l}\text { Corrected } \\
\text { Item-Total Cor- } \\
\text { relation }\end{array}$ & $\begin{array}{l}\text { Squared Mul- } \\
\text { tiple Correla- } \\
\text { tion }\end{array}$ & $\begin{array}{l}\text { Cronbach's } \\
\text { Alpha if Item } \\
\text { Deleted }\end{array}$ \\
\hline $\begin{array}{c}\text { I believe the oral health care of } \\
\text { older people is an important part } \\
\text { of nursing care }\end{array}$ & 18.8 & 2.03 & 0.35 & 0.76 & 0.58 \\
\hline $\begin{array}{l}\text { I am comfortable looking into the } \\
\text { mouths of older people }\end{array}$ & 19 & 1.29 & 0.53 & 0.83 & 0.44 \\
\hline $\begin{array}{c}\text { I am comfortable assisting older } \\
\text { people with their daily oral hy- } \\
\text { giene care }\end{array}$ & 19.2 & 1.31 & 0.43 & 0.53 & 0.52 \\
\hline $\begin{array}{l}\text { I would like to learn more about } \\
\text { the oral health care needs of older } \\
\text { people }\end{array}$ & 18.93 & 1.78 & 0.36 & 0.71 & 0.56 \\
\hline $\begin{array}{l}\text { I would like to learn more about } \\
\text { how nurses can work with other } \\
\text { health professionals in providing } \\
\text { oral care to older people }\end{array}$ & 19 & 1.86 & 0.23 & 0.7 & 0.61 \\
\hline
\end{tabular}

Table 3: Reliability statistics for the revised attitude scale. 
- Omega test for items in the revised attitude section: This estimate of omega was based on the factor loadings of a forced single-factor maximum likelihood factor analysis using SPSS' built in FACTOR procedure.

\section{Reliability Omega.68}

\begin{tabular}{lcccc}
\multicolumn{5}{c}{ Item means, standard deviations (SD), and estimated loadings: } \\
Mean & SD & Loading Error Variance \\
K1 & 4.93 & .26 & .21 & .02 \\
K2 & 4.73 & .59 & .59 & .00 \\
K3 & 4.53 & .64 & .38 & .27 \\
K6 & 4.80 & .41 & .02 & .17 \\
K7 & 4.73 & .46 & -.01 & .21
\end{tabular}

Face and content validity: Questionnaire items were evaluated for clarity of language, consistency in style and format, readability, and organisation. At the end of the questionnaire, an open-ended discussion section (Attachment 2) allowed participants to provide feedback on the clarity of instructions, the wording of items, and general organisation.Comments from participants confirmed that the instructions were easy to follow, the wording of items was clear, and that there were no technical issues with completing the questionnaire in the online format. The time needed to complete the questionnaire ranged from 8-15 minutes.

Construct validity: All items in the perception of self-efficacy and revised attitude sections of the questionnaire showed appropriate item-total correlations greater than 0.2 (Tables 1-3). Two items in the knowledge section had low item-total correlations; they were re-worded for clarity and retained.

\section{Discussion}

This study developed and pilot-tested a 49-item questionnaire that nursing students can complete to evaluate their readiness for providing oral health care to older adults. The questionnaire can also document students' perceptions of how academic and clinical education about oral health care is included in their nursing programs and the influence of factors such as age, gender, education, and experience on students' attitudes about providing oral health care to older people. The questionnaire can be used as a pre-post survey at the beginning of a specific unit about oral health care to provide a critical needs assessment about where students are, what they want to accomplish, and what they have accomplished. Teachers and academic institutions can use this questionnaire in their programs to gain a greater understanding of students' knowledge and competencies in providing oral health care to older people. The questionnaire addresses the need for instruments to measure-nursing students' knowledge, perception, and attitude towards providing oral health care [11]. The development of the questionnaire adhered to a systematic approach in the generation and organisation of items. The internal consistency of the 5-point scales used for the perception of self-efficacy, knowledge, and attitude items, and face, content and construct validity of the questionnaire were satisfactory. The short and concise structure of the questionnaire makes it practical and feasible to measure students' perception of self-efficacy, knowledge of oral health care for older people, and their attitude toward providing such care. The questionnaire can be completed in 8-15 minutes. Participants commented that the questions made them realise the need to learn more about oral health care for older people.

The use of a 5-point Likert-type response scale enables a more detailed statistical analysis of responses compared to "Yes, No, Do Not Know" responses after the administration of the questionnaire [19]. There is substantial evidence that "Do Not Know" options do not improve measurement or quality of data as they frequently reflect a respondent's ambivalence or self-protection rather than a genuine opinion [25]. In response to participants' suggestions, space for additional comments was added where appropriate.

The evaluation of both knowledge and attitude in the questionnaire is useful as both can significantly affect one's intention to practice a certain behaviour. The negative attitude of nurses can potentially compromise the quality of oral care received by older people [21]. The questionnaire also provides the opportunity for instructors and nursing students to compare students' knowledge with their perception of self-efficacy, identifying and understanding the potential disconnect between what students know and what students think they know. The questionnaire can facilitate a better understanding of barriers to effective oral education in nursing programs and ways in which these barriers can be addressed. This understanding will facilitate the effective incorporation of oral health education and clinical practice in nursing programs that do not yet include a focus on oral health care. Such education and practice are vital to support the leading role nurses play in the provision of evidence-based oral health care for older people, across all health care settings. Early exposure of nursing students to education and clinical practice in oral health care in their university programs will help prioritise the need for older people to receive effective oral health care and enable students to understand how such care is an important component of holistic nursing care.

\section{Limitations}

The development of this questionnaire was not without challenges. Nurses who were experienced clinical researchers provided written feedback during the item generation process. However, all were all members of one institution and so may have shared a similar perspective on the topic. Another limitation was the small sample size for the pilot study. The COVID-19 pandemic brought many personal challenges to everyone's lives; thus, the recruitment of participants was not an easy task. A larger sample size is needed to confirm the initial psychometric results and enable factor analysis and criterion validity.

In developing this questionnaire, the focus was on nursing practice in Australia. As reliability and validity can be influenced by context and setting, the completion of this questionnaire by nursing students in programs in other countries and diverse locations will ensure its relevance or need for revision. It is 
important to note that the knowledge section items are based on current Australian evidence-based guidelines. These guidelines are relevant to other Organisation for Economic Co-operation and Development (OECD) countries. As guidelines are updated regularly with advances in dentistry and clinical nursing practice, the questionnaire may need to be revised to ensure content accuracy and revalidation.

A further consideration is where to place opportunities for feedback if participants leave the survey early. For this questionnaire, feedback questions were placed at the end, as is typical, but this prevented receiving feedback from the six participants who did not complete the questionnaire. However, participants may decide not to complete sections of any questionnaire and still provide feedback at the end, so this may not be a viable concern.

\section{Conclusion}

This 49-item questionnaire, which demonstrates adequate face, content, and construct validity, and reliability, can be completed in 8-15 minutes. The questionnaire is a helpful beginning to systematically evaluate what nursing students have learned about oral health care for older adults in their Bachelor of Nursing programs, and their perception and attitude about providing such care. Completion of the questionnaire by a larger number of nursing students will be valuable to confirm these initial psychometric results.

\section{Acknowledgements}

We would like to acknowledge all the experts and nursing students who donated their time to provide feedback on the development of the questionnaire. Also, we would like to thank the Centre for Rural Health and the University of Tasmania for providing opportunities for the first author to develop her research skills.

\section{Ethics approval and consent to participate.}

Ethics approval was received from the Tasmania Social Sciences Human Research Ethics Committee - H0020263. Consent for voluntary participation was obtained from all participants, and confidentiality was maintained at all levels.

\section{Funding}

The first author is supported by a Department of Health, Rural Health Multidisciplinary Training Program scholarship, and a University of Tasmania Research Scholarship for doctoral studies. The funding bodies played no part in the design of the study, collection, analysis, and interpretation of data, nor in writing this manuscript.

\section{References}

1. Hearn $L$ and Slack-Smith $L$ (2015) Oral health care in residential aged care services: barriers to engaging health-care providers. Australian Journal of Primary Health 21: 148-156.
2. Gil-Montoya JA, de Mello ALF, Barrios R, Gonzalez-Moles MA, Bravo $M(2015)$ Oral health in the elderly patient and its impact on general well-being: a nonsystematic review. Clincal Interventions in Aging. 10: 461-467.

3. Petersen PE, Kandelman D, Arpin S, Ogawa H (2010) Global oral health of older people-call for public health action. Community Dental Health 27: 257-67.

4. Ramsay SE, Papachristou E, Watt RG, Tsakos G, Lennon LT, Papacosta AO, et al. (2018) Influence of Poor Oral Health on Physical Frailty: A Population-Based Cohort Study of Older British Men. Journal of the American Geriatrics Society 66: 473-479.

5. Kandelman D, Petersen PE, Ueda H (2008) Oral health, general health, and quality of life in older people. Special care in dentistry : official publication of the American Association of Hospital Dentists, the Academy of Dentistry for the Handicapped, and the American Society for Geriatric Dentistry 28: 224-236.

6. Grönbeck Lindén I, Hägglin C, Gahnberg L, Andersson P (2017) Factors Affecting Older Persons Ability to Manage Oral Hygiene: A Qualitative Study. JDR Clinical \& Translational Research 2: 223-232.

7. Royal Commission into Aged Care Quality and Safety. Interim Report: Neglect [press release]. Australia. 2019 [cited 2021 june 21].

8. León S and Giacaman RA (2020) COVID-19 and Inequities in Oral Health Care for Older People: An Opportunity for Emerging Paradigms. JDR Clinical \& Translational Research 5: 290-292.

9. Shahid Z, Kalayanamitra R, McClafferty B, Kepko D, Ramgobin D, Patel R, et al. (2020) COVID-19 and older adults: what we know. Journal of the American Geriatric Society 68: 926-929.

10. Coker E. Nurses' oral hygiene care practices with hospitalised older adults in postacute settings. International Journal of Older People Nursing.12(1).

11. Bhagat $\mathrm{V}$, Hoang $\mathrm{H}$, Crocombe LA, Goldberg LR (2020) Incorporating oral health care education in undergraduate nursing curricula - a systematic review. BMC Nursing 19: 66.

12. Patterson Norrie T, Villarosa AR, Kong AC, Clark S, Macdonald $S$, Srinivas R, et al. (2020) Oral health in residential aged care: Perceptions of nurses and management staff. Nursing open 7: 536-546.

13. Filej B and Kaucic B (2013) Holistic nursing practice. South Eastern Europe Health Sciences Journal. 3: 1-7.

14. Haresaku S, Monji M, Miyoshi M, Kubota K, Kuroki M, Aoki H, et al. (2018) Factors associated with a positive willingness to practise oral health care in the future amongst oral healthcare and nursing students. European Journal of Dental Education 22: e634-e643.

15. Chan JC and Chin LS (2017) Oral health knowledge and psychological determinants of oral health behavior of nursing students. Journal of Health Psychology 22: 79-88.

16. Dolce MC (2014) Integrating oral health into professional nursing practice: an interprofessional faculty tool kit. Journal of Professional Nursing 30: 63-71.

17. Wan TT (2014) A transdisciplinary approach to health policy research and evaluation. International Journal of Public Policy 10: 161-177.

18. Boateng GO, Neilands TB, Frongillo EA, Melgar-Quiñonez HR, Young SL (2018) Best Practices for Developing and Validating Scales for Health, Social, and Behavioral Research: A Primer. Frontiers in Public Health 6: 149. 
19. Al-Ansari AM, Suroor SN, AboSerea SM, Abd-El-Gawad WM (2019) Development of palliative care attitude and knowledge (PCAK) questionnaire for physicians in Kuwait. BMC Palliative Care 18: 1-18.

20. Hall A (2005) Defining nursing knowledge. Nursing times 101: 34-37.

21. Price $B$ (2015) Understanding attitudes and their effects on nursing practice. Nurs Stand 30: 50-57.

22. Dogan B (2013) Differences in oral health behavior and attitudes between dental and nursing students. Clinical and Experimental Health Sciences 3: 34.

23. Pai M, Ribot B, Tane H, Murray J (2016) A study of periodontal disease awareness amongst third-year nursing students. Contemporary Nurse 52: 686-695.

24. Clemmens D, Rodriguez K, Leef B (2012) Knowledge, attitudes, and practices of baccalaureate nursing students regarding oral health assessment. Journal of Nursing Education 51: 532-535.

25. Krosnick J, Presser S, Building A-S (2009) Question and Questionnaire Design. Handbook of Survey Research.

26. Fayers PM and Machin D (2013) Quality of life: the assessment, analysis and interpretation of patient-reported outcomes. $2^{\text {nd }}$ ed.John Wiley \& Sons.
27. Zeraatkar D, Obeda M, Ginsberg JS, Hirsh J (2017) The development and validation of an instrument to measure the quality of health research reports in the lay media. BMC Public Health 17: 343.

28. Tsang S, Royse CF, Terkawi AS (2017) Guidelines for developing, translating, and validating a questionnaire in perioperative and pain medicine. Saudi Journal of Anaesthesia 11: S80-S89.

29. Bolarinwa $O$ (2015) Principles and methods of validity and reliability testing of questionnaires used in social and health science researches. Nigerian Postgraduate Medical Journal 22: 195-201.

30. Taber KS (2018) The Use of Cronbach's Alpha When Developing and Reporting Research Instruments in Science Education. Research in Science Education 48: 1273-1296.

31. Hayes AF and Coutts JJ (2020) Use omega rather than Cronbach's alpha for estimating reliability. But Communication Methods and Measures 14: 1-24.

32. Trizano-Hermosilla I and Alvarado JM (2016) Best alternatives to Cronbach's alpha reliability in realistic conditions: congeneric and asymmetrical measurements. Frontiers in Psychology 7: 769. 
Attachment 1: Questionnaire to test perception, knowledge, and attitude of nursing students in providing oral health care to older people and associated influential factors.

\section{Section 1: Background information}

Please click on the most appropriate box or write in the space provided.

1. Please specify your country of birth.

$\square$ Australia

$\square$ Other, please specify

2. Where did you spend most of your time in the last 10 years before you enrolled in a Bachelor of Nursing program?

$\square$ Major city (more than 50,000 residents)

$\square$ Regional, rural, or remote area (less than 50,000 residents)

Approximately equal time was spent in a major city and a regional, rural, or remote area

Other, please specify

3. Which university and campus are you attending?

University name

Campus name....

4. What is your age group?

18 - less than 30 years

30 - less than 40 years

40 - less than 50 years

50 - less than 60 years

60 years and over

5. What is your gender?

$\square$ Female

$\square$ Male

$\square$ Other

$\square$ Prefer not to disclose

\section{Section 2: Education and training}

The next set of questions relates to your education, training, and experiences in providing oral health care to older adults. The terms oral health care, and older people used in this questionnaire are described as below:

For nursing practice, oral health care entails ensuring daily oral care, being able to complete an oral health screening, and collaborating with dental, medical, and allied health professionals when required.

Older people referred to people as having a chronological age of 65 years and above.

Please click on the most appropriate box or write in the space provided for the questions below.

6. Have you provided oral health care to older people in your practicum experiences?

$\square$ Yes

No (If “no”, please move to Question 7)

Comment....

6a. Where have you provided this oral health care? (Select all that apply)

$\square$ Residential aged care

Independent living accommodation

A client's home

$\square$ Hospital

Other, please specify 
6b. What oral health care activities did you provide? (Select all that apply)

$\square$ Oral health checks

Making dental referral

Oral health care planning

Oral hygiene tasks

$\square$ Using an oral health product e.g. saliva substitutes, desensitising agents, denture cleaning tablets, fluoride varnishes

$\square$ Oral health care education

Other, can you please briefly describe.

7. Did you receive any education or training in oral health care for older people in your current Bachelor of Nursing program?

$\square$ Yes

No (If "no", please move to Question 8)

Comment:

7a. How much time, would you estimate, was spent on the topic of oral health care for older people?

$\square$ Less than 1 hour

1-2 hours

3-5 hours

$\square$ Other (please specify approximate hours)

7b. What type of oral healthcare education have you received?

$\square$ Practical

$\square$ Theoretical

$\square$ Both practical and theoretical

Comment:

7c. Have you learnt about the following oral health products? (Select all that apply)

$\square$ Interdental cleaning aids (dental floss or tapes, interdental brushes or piksters)

Mouthwashes

$\square$ Saliva substitutes

$\square$ Water hydration

$\square$ Desensitising agents

$\square$ Lip balms

$\square$ Denture cleaning tablets and pastes

$\square$ Denture adhesive pastes

$\square$ Fluoride varnishes

I have not learned any of the above

$\square$ Other, please specify

7d. Have you received training in the following oral health checks? (Select all that apply)

Presence and condition of natural teeth

Presence and condition of dentures

Condition of the lips

Condition of the gums and oral tissues

Condition of saliva

Condition of the tongue

Oral pain

Oral cleanliness

Swallowing ability

Nutritional status/risk

I have not been trained in any of the above 
Other, please specify

8. Did you receive oral health care education or training for older people before your current Bachelor of Nursing program?

$\square$ Yes

8a. If yes, when did you receive this oral healthcare education or training? (Select all that apply)

$\square$ In previous nursing studies, e.g. certificate or other diploma courses

$\square$ In previous work experiences in older people's care

$\square$ Other, please specify.

\section{Section 3: Perception of oral healthcare knowledge and skills}

9. The statements below ask about your perception of your knowledge and skills about providing oral healthcare to older people. Please read and respond to each statement by clicking in the appropriate column.

\begin{tabular}{|c|c|c|c|c|c|}
\hline Statements & $\begin{array}{l}\text { Strongly } \\
\text { agree }\end{array}$ & Agree & $\begin{array}{l}\text { Neither } \\
\text { agree nor } \\
\text { disagree }\end{array}$ & Disagree & $\begin{array}{l}\text { Strongly } \\
\text { disagree }\end{array}$ \\
\hline $\begin{array}{l}\text { 1. I understand the factors affecting the } \\
\text { oral health of older people }\end{array}$ & & & & & \\
\hline $\begin{array}{l}\text { 2. I am aware of effective daily oral } \\
\text { health activities }\end{array}$ & & & & & \\
\hline $\begin{array}{l}\text { 3. I am trained in making an } \\
\text { appropriate, timely referral to a } \\
\text { dentist for oral health assessment and } \\
\text { care of older people when required }\end{array}$ & & & & & \\
\hline $\begin{array}{l}\text { 4. I understand the relationship between } \\
\text { oral and systemic health }\end{array}$ & & & & & \\
\hline $\begin{array}{l}\text { 5. I am confident in training and } \\
\text { supervising in providing oral health } \\
\text { care to older people }\end{array}$ & & & & & \\
\hline
\end{tabular}

\section{Section 4: Knowledge of oral healthcare of older people}

10. The statements below address your actual knowledge of oral healthcare for older people. There are 15 statements. Please read and respond to each statement by clicking in the appropriate column

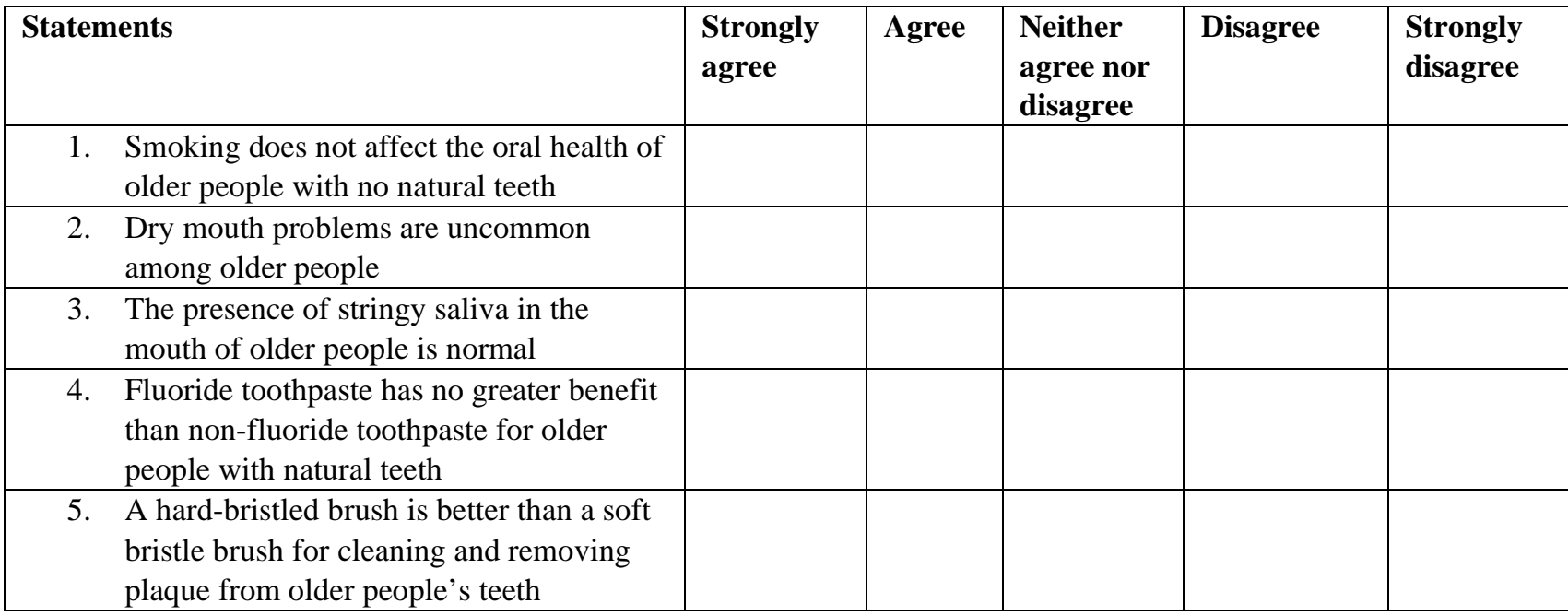




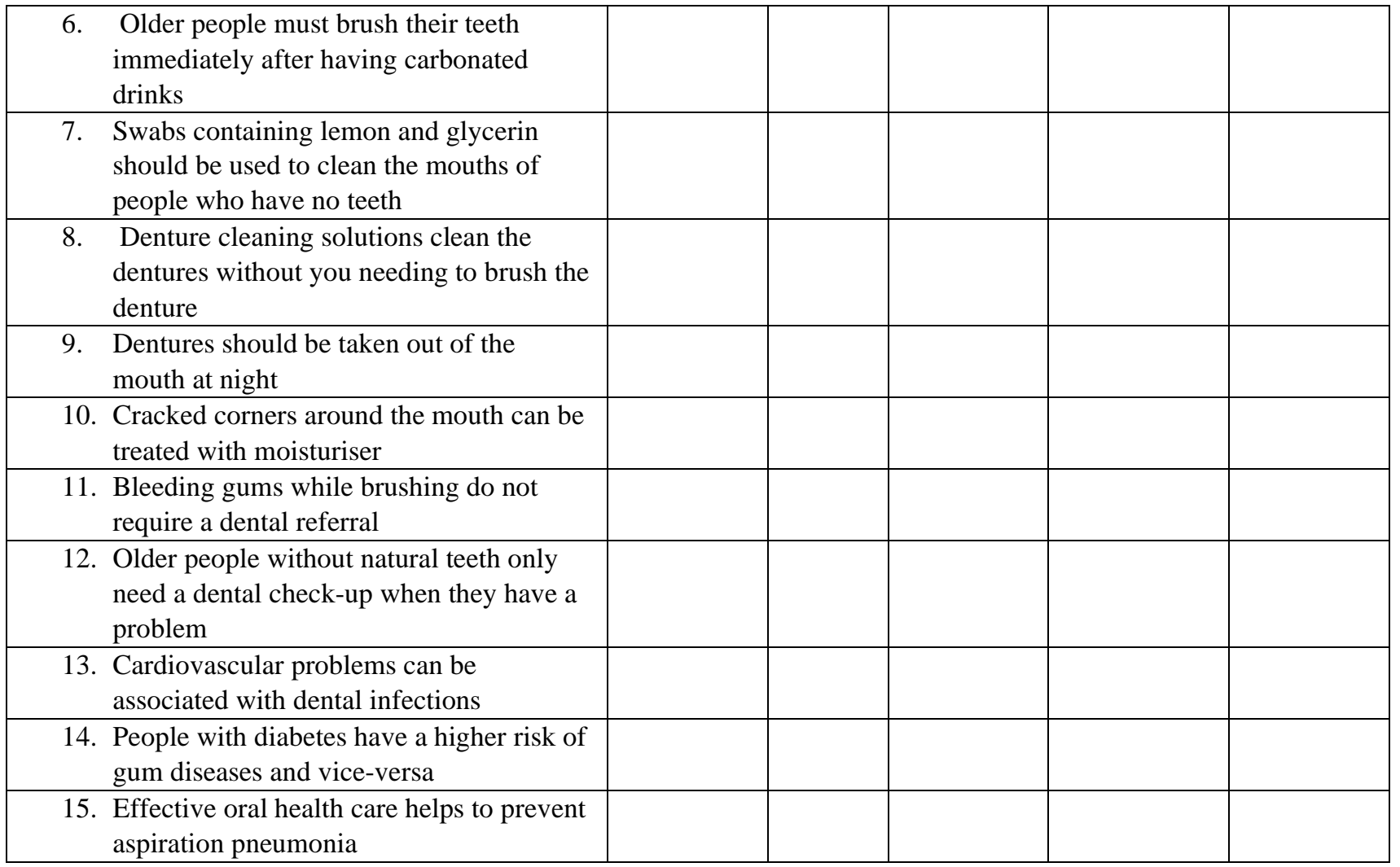

\section{Section 5: Attitudes towards oral healthcare provision to older people}

11. The statements below ask about how you feel in providing oral healthcare to older people. Please read and respond to each statement by clicking in the appropriate column

\begin{tabular}{|c|l|l|l|l|l|}
\hline Statements & $\begin{array}{l}\text { Strongly } \\
\text { agree }\end{array}$ & Agree & $\begin{array}{l}\text { Neither } \\
\text { agree nor } \\
\text { disagree }\end{array}$ & Disagree & $\begin{array}{l}\text { Strongly } \\
\text { disagree }\end{array}$ \\
\hline $1 . \quad \begin{array}{l}\text { I believe the oral health care of older } \\
\text { people is an important part of nursing } \\
\text { care }\end{array}$ & & & & & \\
\hline $2 . \quad \begin{array}{l}\text { I am comfortable looking into the } \\
\text { mouths of older people }\end{array}$ & & & & & \\
\hline $3 . \quad \begin{array}{l}\text { I am comfortable assisting older people } \\
\text { with their daily oral hygiene }\end{array}$ & & & & & \\
\hline $4 . \quad \begin{array}{l}\text { I would like to learn more about the } \\
\text { oral health care needs of older people }\end{array}$ & & & & & \\
\hline 5. $\begin{array}{l}\text { I would like to learn more about how } \\
\text { nurses can work with other health } \\
\text { professionals in providing oral care to } \\
\text { older people }\end{array}$ & & & & & \\
\hline
\end{tabular}

\section{Section 6: Your oral health care behaviour}

Please click the most appropriate box or write in the space provided

Q12. How often do you brush your teeth?
$\square$ Less than daily
Once daily
Twice daily 
Thrice daily

Other, please specify

Q13. How often do you use dental floss, tape or an interdental brush to clean between your teeth, other than to remove food particles stuck between your teeth?

$\square$ Less than daily

Once daily

Twice daily

Other, please specify.

Q14. Which is your usual reason for visiting a dental professional?

$\square$ Regular check-up

$\square$ Problem

Other, please specify

Q15. How anxious are you about visiting a dentist?

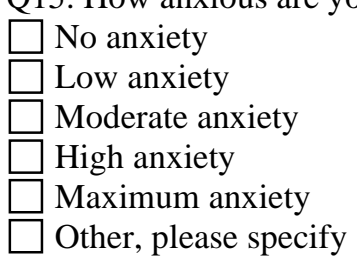

Section 7: Incorporation of oral health content in the nursing curriculum

Please click on the most appropriate box or write in the space provided.

Q16. Do you think the current nursing curriculum prepares nurses to provide effective oral health care to older people?

Yes

No

If no, what gaps in the curriculum can you identify about oral health care for older people?

Q17. What other factors could impact the provision of effective oral health to older people?

Q18. Do you have any recommendations to improve the competency of graduating nurses to deliver effective oral health care to older people?

Yes

No

If yes, what are your recommendations?

Thank you so much for your time in completing this survey. As you think back on the questions, is there anything you would like to add regarding the role of nurses in maintaining the oral health of older people? 
Attachment 2: Feedback questionnaire

Q1. Were the instructions for completing the survey clearly written?

Q1a. If no, can you please provide details of the instructions which were not clear.

Q2. Were the questions clear and easily understandable?

Q2a. If no, can you please provide details about questions which were not clear.

Q3. Do you have any suggestions regarding the addition or deletion of questions, the clarification of instructions, or improvements in format?

Q3a. If yes, what suggestions do you have?

Q4. How long the survey took to complete? 